\title{
LANGUAGE AND LITERACY STRATEGIES IN TEACHING MATHEMATICS: DO THEY CORRELATE WITH STUDENTS' PSYCHOLOGICAL NEEDS?
}

\author{
JOHN RYANN F. GALLEGO
}

La Salle Academy, Iligan City, Philippines

\begin{abstract}
Premised on a constructivist theory and self-determination theory, the current study explores the relationship between students' performance in mathematics and their psychological needs as a result of using language and literacy strategies. Using a socio cognitive-transformative materials design model, eighty-six grade four students from a private school in Northern Mindanao were selected as respondents to answer the pretest and posttest assessments, the modified Basic Need Satisfaction Scale questionnaire, and the Focused Group Discussion checklist. Moreover, through a mixedmethod research design, frequency and percentage distribution, weighted mean, paired-sample t-test, Pearson Correlation Coefficient, linear regression, classroom observation, and FGD analysis were used to determine if the use of language and literacy strategies in teaching mathematics helps improve students' performance and how it correlates to their psychological needs. On the basis of the results of this research, it can be concluded that the use of language and literacy strategies helps improve the math performance of students from both class groups regardless of their section. Moreover, results suggest that when more process types of assessments are given to students, their need for competence also increases. Hence, this thesis hopes to offer new pedagogical approaches to math teachers as they cater to $21^{\text {st }}$ century learners and how to meet the demands of an integral education.

KEYWORDS: Language and Literacy Strategies, Mathematics Teaching, Psychological Needs, Assessment \& Education
\end{abstract}

Received: Jun 20, 2017; Accepted: Jul 10, 2017; Published: Jul 18, 2017; Paper Id.: IJESRAUG20173

\section{INTRODUCTION}

\section{Background Objectives and Goals}

Authentic literacy or literacy is integral to any educational goals which are what to teach and how to teach (Schmoker, 2011). It is the "spine" that "holds everything together" in all subject areas (Phillips \& Wong, 2010, p. 41), provides a purposeful and usually argumentative - reading, writing, and talking (Lunsford \& Ruszkiewicz, 2009), and is the key to learning both content and thinking skills (Schmoker, 2011). There could have been several definitions of authentic literacy, but there is also no singular definition for such construct. If this is put into a bigger context, literacy is a fundamental human right and the foundation for lifelong learning (United Nations Educational, Scientific, and Cultural Organizations [UNESCO], 2015). Furthermore, UNESCO (2015) believes that it is fully essential to social and human development in its ability to transform lives. Hence, students become more literate as they develop the knowledge; skills and dispositions interpret and use language confidently for learning and communicating in and out of school and for participating effectively in society (Australian Curriculum, 2014).

On the other hand, a school paradigm may define authentic literacy as something pedagogically - that only people who commonly use it may know its real meaning (Duke, Purcell-Gates, Hall, \& Tower, 2015). Thus, this term must always be paired with the word, instruction. True enough for teachers that authentic literacy is the 
reading and writing of real-life texts for real-life purposes in the literacy-learning classroom (Authentic Literacy Instruction, 2015, p. 1). In this case, it becomes an essential skill for students in becoming successful learners and in building a foundation for success in all learning areas (Melbourne Declaration on Educational Goals for Young Australians [MCEETYA], 2008) as cited in Australian Curriculum (2014). Thus, the success of students in any learning area depends on the significant, identifiable and distinctive use of authentic literacy that is important for learning and representative of the content of that learning area. In all cases, content areas like language and arts, social studies, science, and mathematics have followed sets of standards to teach to students quarterly (Department of Education Revised Curriculum, 2013). Nevertheless, problems on how these standards are taught have become perennial in many schools. Hence, this concern is addressed in authentic literacy as defined by the aforementioned authors and agencies.

Among these content areas, students find mathematics academically challenging. In fact, in Singham and Steen (as cited in Schmoker, 2011), there are more students who fail in math than any other subject, a fact that contributes disproportionately to academic frustration and dropout rates. Furthermore, Deborah Meier (2010), an urban educator and author, supported this idea when she said that many have begun to ask how much sense it makes to require all students to learn the most abstract, algebra-based mathematics, especially if it cannot be shown to have any genuine connection to the workplace. With this context in teaching mathematics, it has been the teachers' concern that students always find difficulty in comprehending math word problems due to poor levels of comprehension, limited vocabulary, and less exposure of students to these kinds of methods as explained by Schmoker (2011) and Meier (2010). That is why the researcher hypothesizes that with the use of language and literacy strategies in teaching mathematics, the experiences of students in a math class become more differentiated, interesting, creative, and innovative in addressing those issues concerning students' difficulties in mathematics.

Looking at this problem, the researcher has read a number of educational reforms in Asia that pertain to how they improved their curriculum to address the demands of the $21^{\text {st }}$ century education. One of which is how Philippine education made changes in their Basic Education Curriculum to address issues in education. Although there are diverse issues in the Philippine education, the current study focuses on the use of language and authentic literacy in teaching mathematics to correlate students' performance in math with their psychological needs. The researcher found out that there has been a gap between improving the strategies in teaching mathematics and the reasons why students perform better in math activities. In the theory of self-determination by Ryan and Deci (2000), they explained that human beings are driven to perform on something because their basic psychological needs, namely, autonomy, competence, and relatedness are satisfied accordingly. Hence, the researcher would like to fill-in the gap of this literature by considering the three basic psychological needs in choosing the kind of language and literacy strategies in teaching mathematics. Through this, it will help the math teacher make confirmations as to the effective formulation of teaching strategies in the future in relation to the students' basic psychological needs.

\section{Theoretical Framework}

The authentic literacy strategies used in teaching mathematics were anchored on the socio-cognitivetransformative model in second language (L2) pedagogy which aims to produce learners who are socially participative, multi-literate, communicatively competent, and lifelong learners (Barrot, 2014). The researcher believes that the constructivist point of view is the most appropriate model to design a learning module that uses language and authentic literacy strategies in teaching mathematics. Just like Barrot's (2014) material design model, this one integrates the two 
constructivist theories of learning: socio-cognitive theory and transformative learning. Socio-cognitive theory is a new perspective that claims the interdependence between social and cognitive aspects of language (Atkinson 2002) and puts greater emphasis on using language in authentic social contexts (Warschauer and Healey 1998). Transformative learning, on the other hand, relates to actual behavior that learners should manifest to contribute to and participate in the community where they live in (Mezirow, 2009). These combined theories served as a strong foundation for specifying the aspects of the learning module that was designed: the learning goal, objectives, activities, assessments and tasks of learners that would make a radical change in teaching mathematics.

On the other hand, Self-Determination Theory (SDT) is an approach to human motivation and personality that uses traditional empirical methods while employing an organismic meta-theory that highlights the importance of humans' evolved inner resources for personality development and behavioral self-regulation (Ryan, Kuhl, \& Deci as cited in Ryan and Deci, 2000, p. 28). This concept of SDT explains the inherent growth tendencies and innate psychological needs of human beings which are the basis for their self-motivation and personality integration. At best, this theory is chosen to define math performance in the area of the psychological needs such as competence, relatedness, and autonomy (Ryan \& Deci, 2000). These are essential for facilitating the optimal functioning of the natural propensities for growth, as well as for constructive social development and personal well-being. Previous studies and principles have confirmed the importance of applying authentic literacy in teaching mathematics as one manifestation of holistic education. Nonetheless, no one has yet explored these psychological needs in relation to authentic literacy in teaching mathematics. In this regard, the problem has been simplified to: which psychological need is greatly correlated to students' performance in mathematics if applied to authentic literacy?

\section{Statement of the Problem}

This paper further aims to answer the following essential research questions:

- Is there a difference in students' pretest and posttest results?

- Between the homogeneous and heterogeneous classes, which is greatly affected by the use of language and literacy strategies in teaching mathematics?

- By using language and literacy strategies in teaching mathematics, which psychological need of students is highly or least satisfied:

- Autonomy;

- Competence;

- Relatedness?

- Is there a significant relationship between the students' psychological needs satisfaction and their posttest results in mathematics?

- What are the benefits of using language and literacy strategies in teaching mathematics to students?

\section{Hypotheses}

- The various strategies of language and authentic literacy will have no significant relationship to higher levels of achievement in mathematics. 
- The students' posttest results in math will have no significant correlation to students' psychological needs like competency, relatedness, and autonomy.

\section{METHODS}

\section{Research Design}

The researcher embarked on a mixed-method research design (Barney 2015, University of Southampton) where quantitative, qualitative, and experimental designs were utilized. Hence, the present study used students' pre-test and posttest results and the FGD results to determine the significant difference in using these languages and literacy strategies in teaching mathematics and in correlating the post-test results to the students' psychological needs.

On the other hand, this study also followed an experimental design, particularly a two-group pre-test-post-test experimental design of the homogeneous and the randomly chosen heterogeneous class where there was an attempt by the researcher to maintain control over all factors that would affect the result of an experiment.

\section{Participants}

In the exploratory phase of the current study, two homerooms with a total of eighty-six students in the grade four level from a private school in one of the highly urbanized cities in Northern Mindanao participated in the study. One homogeneous class with forty-five students and one randomly chosen heterogeneous class with forty-one students participated as the respondents in this study.

\section{Data Gathering Method}

There were three ways used in gathering the most important data in this study. First was the use of the module of the teacher in presenting and discussing the lessons in math for the first quarter. In writing the module, the researcher asked two math teachers to co-author his module for it to become more valid and reliable. Second was the utilization of the pretest and posttest results of the students after they performed in the language and literacy strategies. Third was done through conducting FGDs or focused group discussions using a checklist with the select random pupils and through conducting an observation with the teacher. The results from the data gathered were analyzed and treated with utmost confidentiality to protect the aforementioned respondents.

\section{Instrument and Scoring Procedure}

The present study made use of instruments that were already validated by authors like Heidema (2009), Matheny (2009), and Hintz and Kazemi (2014). These strategies were validated by the said authors in their research studies as published in the journal entitled, "Adolescent Literacy In Perspective" on February 2009. Among these strategies used in the module are the K-N-W-S, SQRQCQ, the three-level guide, problem roulette, RAFT, and process log. All these instruments employed language and authentic literacy strategies that are purposely made to teach mathematics. To assure validity and reliability of these strategies, the learning module that was designed was co-authored and validated by Ms. Leila T. Simbajon, a math coordinator and Ms. Ana T. Liguan, a grade 4 math teacher. In the Explore part of the module, activities, assess students' prior knowledge of facts and skills about the standards of the quarter. On the other hand, in Firm-up stage, activities help students acquire facts and skills about the standards that are given to them. To acquire information, students have to do varied language and literacy strategies that involve collaboration, self-regulation and communication in learning mathematics concepts. As the module progresses, students will make the meaning of the facts 
and skills they acquired in the previous activities. Lastly, as the module ends, students will transfer the facts and skills they acquired and the meaning they made in the previous activities of the learning module.

In correlating students' performance in mathematics to their psychological needs, the researcher made use of the students' posttest results in mathematics in the first quarter; then, correlated them to the results of their Basic Need Satisfaction Scale Questionnaire (BNSSQ). The researcher used the said scale (SDT, 2015) but modified some items to fit the purpose of measuring the experiences of students in learning mathematics when applied to language and literacy strategies. Likewise, the scoring of the instrument was made by forming three subscale scores, one score for the degree to which the student experienced satisfaction with each of the three needles. Moreover, the said instrument was pilot tested to 25 randomly selected students in grade four, school year 2015-2016, and as a result, its reliability, value did not reach 70\%, which is the acceptable level of reliability. Hence, modifications on the items were made to increase its reliability value.

Another instrument that was used in this study was a Focused Group Discussion (FGD) questionnaire or checklist to measure the benefits and experiences of the respondents in using the designed module. To assure validity, the choices in the checklist in measuring the benefits were adapted from the attributes of a good mathematics teaching by Wilson and Stinson (2005).

\section{Statistical Treatment}

The following treatments of data were used in the presentation of the results and discussion section of this paper.

Frequency and Percentage Distribution: The demographic profile of the respondents was presented using a frequency distribution. Percentage distribution is used in the formative assessment result of the respondents by class group.

Weighted Mean: In the presentation of the individual items in the basic needs satisfaction of the respondents by class group, the weighted mean was used. Each of the weighted mean score has equivalent response category and verbal description which is shown in the following scoring procedure.

\section{Table 1}

\begin{tabular}{|c|l|l|}
\hline Weighted Mean & \multicolumn{1}{|c|}{ Response } & Verbal Description \\
\hline $5.01-7.00$ & Very True & Very Satisfied \\
\hline $3.01-5.00$ & Somewhat True & Satisfied \\
\hline $1.00-3.00$ & Not at All True & Not Satisfied \\
\hline
\end{tabular}

Paired-Sample T-test This was used to compare the mean score of the students in the pretest and posttest scores.

Pearson Correlation Coefficient This test was used to determine the degree of linear relationship between the posttest assessment and the basic needs satisfaction.

Linear Regression To determine the significance estimate on the degree of association between the psychological needs of respondents and the students' performance during the post-test when language and literacy strategies in teaching Mathematics was utilized, the linear regression formula was used.

\section{RESULTS AND DISCUSSIONS}

\section{Demographic Statistics}

For a clearer understanding of the results, Table 1 summarizes the distribution of the respondents by class considered as the groups. Forty-five students are included under the homogeneous class and forty-one under the 
heterogeneous class.

Table 2: Distribution of Respondents by Group

\begin{tabular}{|c|l|c|}
\hline \multicolumn{1}{|c|}{ Group } & \multicolumn{1}{|c|}{ Section } & Number of Students \\
\hline Homogeneous & St. Elizabeth & 45 \\
\hline Heterogeneous & St. Clare & 41 \\
\hline Total & & $\mathbf{8 6}$ \\
\hline
\end{tabular}

\section{Pretest and Posttest Assessment Results}

Table 2 presents the overall results in the knowledge and process assessments. The total score now is 20, adding the 8 from the knowledge and 12 in the process type of assessment. Students answered a knowledge type of assessments where they objectively gave their responses and they performed process type of assessment where they responded to openended questions. The latter made use of a rubric to check the responses of the respondents.

Table 3: Percentage Distribution of Combining Knowledge \& Process Assessment Total Scores

\begin{tabular}{|c|c|c|c|c|}
\hline \multirow{2}{*}{ Score } & \multicolumn{2}{|c|}{ St. Elizabeth } & \multicolumn{2}{c|}{ St. Clare } \\
\cline { 2 - 5 } & Pretest & Posttest & Pretest & Posttest \\
\hline $0-5$ & 7 & 0 & 49 & 2 \\
\hline $6-10$ & 36 & 4 & 39 & 37 \\
\hline $11-15$ & 58 & 24 & 12 & 37 \\
\hline $16-20$ & 0 & 71 & 0 & 24 \\
\hline Mean Score & 10.73 & 16.69 & 6.00 & 12.05 \\
\hline \multirow{2}{*}{ T-Test } & \multicolumn{2}{|l|}{$\begin{array}{l}\text { T-Value }=-12.330 \\
\text { P-Value }=0.000^{*}\end{array}$} & $\begin{array}{l}\text { T-Value }=-8.076 \\
\text { P-Value }=0.000^{*}\end{array}$ \\
\hline
\end{tabular}

Legend: * means posttest scores are significantly higher than pretest scores

\section{DISCUSSIONS}

- There is a significant difference in the students' pretest and posttest scores in mathematics. The significant increase in knowledge and process assessments implies that the use of language and literacy strategies helped the students master the competencies and standards they acquired in the first quarter.

- Between the homogeneous and heterogeneous class groups, it appears that the former has a higher increase of fastest results. This means that the nature and type of language and literacy strategies they performed in the class manifests their level of competency. Likewise, for the heterogeneous class, it can be inferred that despite their ability level, there is a positive increase of their posters results from a good number of them already passed the two types of assessments and their posttest scores are significantly higher compared to their pretest scores.

\section{Satisfaction of Basic Psychological Needs}

Tables 3 to 5 present the basic need satisfaction of the students by class group. Table 3 is the distribution of the individual items for autonomy. On the other hand, Table 4 is the distribution of the individual items for competence. Meanwhile, Table 5 below shows that there are three items that showed different satisfaction level for the two class groups in the need for relatedness. 
Table 4: Basic Need Satisfaction (Autonomy)

\begin{tabular}{|c|l|c|c|c|l|}
\hline \multicolumn{2}{|c|}{ Items } & \multicolumn{2}{c|}{ St. Elizabeth } & \multicolumn{2}{c|}{ St. Clare } \\
\cline { 3 - 6 } & WM & VD & WM & VD \\
\hline 1 & $\begin{array}{l}\text { I feel like I am free to decide for myself in making } \\
\text { answers and solutions. }\end{array}$ & 3.96 & Satisfied & 2.80 & Not Satisfied \\
\hline 6 & $\begin{array}{l}\text { I generally feel free to express my ideas and opinions } \\
\text { when asked to answer in our math class. }\end{array}$ & 4.49 & Satisfied & 4.07 & Satisfied \\
\hline 9 & $\begin{array}{l}\text { In our daily math class, I frequently have to do what } \\
\text { I am told by the teacher. }\end{array}$ & 6.53 & Very Satisfied & 5.51 & Very Satisfied \\
\hline 12 & $\begin{array}{l}\text { My classmates and our math teacher whom I interact } \\
\text { with everyday tend to consider my feelings. }\end{array}$ & 4.56 & Satisfied & 4.93 & Satisfied \\
\hline 15 & $\begin{array}{l}\text { I feel like I can pretty much be myself during math } \\
\text { classes and activities. }\end{array}$ & 3.98 & Satisfied & 3.83 & Satisfied \\
\hline 18 & $\begin{array}{l}\text { There is not much chance for me to decide for myself } \\
\text { how to do things in our math activities. }\end{array}$ & 3.00 & Not Satisfied & 4.24 & Satisfied \\
\hline & $\quad 3.91$ & Satisfied & $\mathbf{3 . 6 5}$ & Satisfied \\
\hline
\end{tabular}

Legend: $\mathrm{WM}=$ weighted mean; $\mathrm{VD}=$ verbal description; (1.00-3.00) $\mathrm{N}=$ Not satisfied; (3.01-5.00) $\mathrm{S}=\mathrm{Satisfied}$; $(5.01-7.00) \mathrm{V}=$ Very satisfied

Table 5: Basic Need Satisfaction (Competence)

\begin{tabular}{|c|l|l|l|l|l|}
\hline \multicolumn{2}{|c|}{ Items } & \multicolumn{2}{c|}{ St. Elizabeth } & \multicolumn{2}{c|}{ St. Clare } \\
\cline { 3 - 6 } & WM & \multicolumn{1}{|c|}{ WM } & VD \\
\hline 2 & $\begin{array}{l}\text { Often, I do not feel very competent or good in performing } \\
\text { in my math class. }\end{array}$ & 3.44 & Satisfied & 3.85 & Satisfied \\
\hline 3 & $\begin{array}{l}\text { People I know tell me I am good at what I do in my math } \\
\text { class. }\end{array}$ & 4.84 & Satisfied & 3.88 & Satisfied \\
\hline 8 & $\begin{array}{l}\text { I have been able to learn interesting new skills recently in } \\
\text { our math classes. }\end{array}$ & 6.69 & Very Satisfied & 5.80 & Very Satisfied \\
\hline 11 & $\begin{array}{l}\text { Most days I feel a sense of accomplishment from what I do } \\
\text { during our math classes. }\end{array}$ & 5.40 & Very Satisfied & 4.73 & Satisfied \\
\hline 13 & $\begin{array}{l}\text { In our math classes, I do not get much of a chance to show } \\
\text { how capable I am. }\end{array}$ & 3.22 & Satisfied & 4.44 & Satisfied \\
\hline 17 & $\begin{array}{l}\text { I often do not feel very capable in performing the activities } \\
\text { in our math class. }\end{array}$ & 3.31 & Satisfied & 3.68 & Satisfied \\
\hline \multicolumn{1}{|c|}{ Grand Mean } & $\mathbf{5 . 1 6}$ & Very Satisfied & $\mathbf{4 . 4 1}$ & Satisfied \\
\hline
\end{tabular}

Legend: $\mathrm{WM}=$ weighted mean; $\mathrm{VD}=$ verbal description; (1.00-3.00) $\mathrm{N}=$ Not satisfied; (3.01-5.00) $\mathrm{S}=\mathrm{Satisfied}$; (5.01-7.00) V = Very satisfied

Table 6: Basic Need Satisfaction (Relatedness)

\begin{tabular}{|l|l|c|c|c|c|}
\hline \multicolumn{2}{|c|}{ Items } & \multicolumn{2}{c|}{ St. Elizabeth } & \multicolumn{2}{c|}{ St. Clare } \\
\cline { 3 - 5 } \multicolumn{2}{|l}{} & WM & VD & WM & VD \\
\hline 5 & $\begin{array}{l}\text { I get along with people that I talk and communicate with } \\
\text { during math class. }\end{array}$ & 5.64 & Very Satisfied & 3.88 & Satisfied \\
\hline 5 & $\begin{array}{l}\text { I pretty much keep to myself my ideas during our math class } \\
\text { and don't like to interact with others. }\end{array}$ & 3.51 & Satisfied & 3.88 & Satisfied \\
\hline 7 & $\begin{array}{l}\text { I consider the people I regularly interact during math class to } \\
\text { be my friends. }\end{array}$ & 5.40 & Very Satisfied & 4.41 & Satisfied \\
\hline 10 & Our math teacher and my classmates care about me. & 5.09 & Very Satisfied & 5.46 & Very Satisfied \\
\hline 14 & $\begin{array}{l}\text { There are not many people that I am close to during math } \\
\text { activities/classes. }\end{array}$ & 2.80 & Not Satisfied & 3.29 & Satisfied \\
\hline
\end{tabular}


Table 6: Contd.,

\begin{tabular}{|c|l|l|l|l|l|}
16 & $\begin{array}{l}\text { The people I interact with regularly in math class do not } \\
\text { seem to like me much. }\end{array}$ & 3.40 & Satisfied & 3.51 & Satisfied \\
\hline 19 & $\begin{array}{l}\text { My classmates and our teacher are generally pretty friendly } \\
\text { towards me during math class. }\end{array}$ & 5.80 & Very Satisfied & 5.20 & Very Satisfied \\
\hline Grand Mean & $\mathbf{5 . 1 6}$ & Very Satisfied & $\mathbf{4 . 4 1}$ & Satisfied \\
\hline
\end{tabular}

Legend: $\mathrm{WM}$ = weighted mean; VD = verbal description; (1.00-3.00) N = Not satisfied; (3.01-5.00) S = Satisfied; (5.01-7.00) $\mathrm{V}=$ Very satisfied

\section{DISCUSSIONS}

- It can be inferred that in terms of making decisions for themselves in making answers and solutions, the respondents from the homogeneous class felt very satisfied. In fact, it was observed that these students exhibited signs of increased self-esteem due to their abilities to make decisions for themselves while performing those language and literacy strategies.

- Findings show that the respondents met the competence level expected of them based on the language and literacy strategies found in the learning module regardless of which group class they belong.

- Both class groups of respondents were satisfied generally with the collaborative tasks and activities, and/or strategies conducted in the classroom in learning mathematics concepts.

- Among the basic psychological needs of the respondents, autonomy, competence, and relatedness were equally satisfied by the use of language and literacy strategies. Nonetheless, the two class groups varied in the level of satisfaction for competence and relatedness needs. It was found that the respondents from the homogeneous class felt that their needs for competence and relatedness were more satisfied compared to the respondents from the heterogeneous group.

\section{Correlation Analysis Result}

Table 6 shows the result of the statistical test employed, specifically the correlation test, for the posttest assessment result and basic needs satisfaction level. The specific variables indicated in the table are those with significant correlation with each other.

Table 7: Correlation Analysis for Posttest and Basic Needs Satisfaction

\begin{tabular}{|c|l|c|c|l|}
\hline \multirow{1}{*}{ Group } & \multicolumn{1}{|c|}{ Pair of Variables } & $\begin{array}{c}\text { r-value (correlation } \\
\text { coefficient) }\end{array}$ & p-value & \multicolumn{1}{|c|}{ Interpretation } \\
\hline \multirow{5}{*}{ St. Elizabeth } & Knowledge vs. Autonomy & 0.187 & 0.220 & No correlation \\
\cline { 2 - 5 } & Knowledge vs. Competence & $0.402^{*}$ & 0.006 & With correlation \\
\cline { 2 - 5 } & Knowledge vs. Relatedness & 0.213 & 0.159 & No correlation \\
\cline { 2 - 5 } & Process vs. Autonomy & 0.153 & 0.315 & No correlation \\
\cline { 2 - 5 } & Process vs. Competence & $0.466^{*}$ & 0.001 & With correlation \\
\cline { 2 - 5 } & Process vs. Relatedness & 0.230 & 0.129 & No correlation \\
\hline \multirow{5}{*}{ St. Clare } & Knowledge vs. Autonomy & 0.150 & 0.348 & No correlation \\
\cline { 2 - 5 } & Knowledge vs. Competence & 0.204 & 0.200 & No correlation \\
\cline { 2 - 5 } & Knowledge vs. Relatedness & 0.178 & 0.266 & No correlation \\
\cline { 2 - 5 } & Process vs. Autonomy & 0.286 & 0.070 & No correlation \\
\cline { 2 - 5 } & Process vs. Competence & $0.385 *$ & 0.013 & With correlation \\
\cline { 2 - 5 } & Process vs. Relatedness & 0.290 & 0.066 & No correlation \\
\hline
\end{tabular}


Legend: * means significant correlation at 0.05 level of significance

\section{DISCUSSIONS}

- Among the psychological needs, the need for competence was positively correlated to the results in the respondents' posttest assessment. Particularly, the process type of assessment is consistently correlated to competence need for both respondents in two class groups. Moreover, the increase of students' performance in math by $28.4 \%$ is attributed to their psychological needs satisfaction.

- The result of the correlation analysis where the posttest process scores significantly correlated with the need satisfaction for competence adheres to the five strands of mathematical proficiency to develop good mathematics teaching that was set by the National Research Council (Leong, 2014). Therefore, the more process type of test and language and literacy strategies are given to students in learning mathematics competencies, the higher is the chance of developing their level of competence.

\section{Regression Analysis: Psychological Needs versus Post Test Results}

Tables 7 present the analysis of the relationship of the three psychological needs in general and the posttest results in mathematics using linear regression. The average of the three basic psychological needs was identified in relation to the students' posttest results.

Table 8: Strength of Relationship between Psychological Need and Posttest Results

\begin{tabular}{|l|c|c|c|c|}
\hline The regression equation in Psychological Need = 3.07 + 0.0985 Post Test Results \\
\hline Predictor & Coef & SE Coef & T & P \\
\hline Constant & 3.0696 & 0.2572 & 11.93 & 0.000 \\
\hline Post Test & 0.09855 & 0.01707 & 5.77 & 0.000 \\
\hline S $=\mathbf{0 . 6 6 3 1} \mathbf{R - S q}=\mathbf{2 8 . 4 \%} \mathbf{R - S q}(\mathbf{a d j})=\mathbf{2 7 . 6 \%}$ & \\
\hline
\end{tabular}

\section{DISCUSSIONS}

- Results show that there is a significant linear relationship between the average of the three psychological needs satisfaction of students and their posttest results after utilizing the language and literacy strategies in teaching mathematics. An empirical model was obtained which states that Psychological Need $=3.07+0.0985$ Post Test Results with an R-squared value of $28.4 \%$.

- The strength of its correlation states that satisfying the psychological needs of students in learning yields to an increase in their mathematical performance. Furthermore, the increase of their performance by $28.4 \%$ is significantly explained by their psychological needs satisfaction. The other $71.6 \%$ can be attributed to other factors.

\section{Benefits Acquired in Math Activities}

As presented in Table 8, most of the students in each class group have acquired benefits in their math activities. The Focused Group Discussion (FGD) conducted by the researcher with 30 randomly selected respondents from both class groups determined the qualitative value of the benefits they acquired in performing the language and literacy strategies in learning mathematics. 
Table 9: Benefits Acquired in Math Activities

\begin{tabular}{|c|l|c|c|}
\hline \multicolumn{1}{|c|}{ Items } & \multicolumn{1}{|c|}{ Percentage of Response } \\
\cline { 2 - 4 } & \multicolumn{1}{|c|}{ St. Elizabeth } & St. Clare \\
\hline 1 & $\begin{array}{l}\text { The activities in our math class build strong relationships between us and our } \\
\text { math teacher. }\end{array}$ & 90 & 90 \\
\hline 2 & $\begin{array}{l}\text { The activities provide intellectually challenging and genuinely engaging } \\
\text { learning. }\end{array}$ & 93 & 90 \\
\hline 3 & $\begin{array}{l}\text { The activities develop learning environments where we feel safe and supported } \\
\text { to take risks in the learning process. }\end{array}$ & 77 & 93 \\
\hline 4 & \begin{tabular}{l} 
The activities shape learning that is relevant and meaningful to us. \\
\hline 5
\end{tabular} & $\begin{array}{l}\text { The activities offer opportunities for us to develop independence and good } \\
\text { habits of learning. }\end{array}$ & 93 \\
\hline 6 & $\begin{array}{l}\text { The activities provide personal support for us based on our teacher's } \\
\text { knowledge of us as learners. }\end{array}$ & 87 & 83 \\
\hline
\end{tabular}

\section{DISCUSSIONS}

- The respondents from both class groups found their math activities in the first quarter for this school year, more challenging, interactive, relevant and meaningful to their lives. They further claimed that the language and literacy strategies they performed in their math class shaped their learning that is relevant to real life. This finding is in consonance with the theories of constructivism, holistic education and the principles of 21 st century learning discussed in the previous section of this paper.

- The implications of these results show that if more language and literacy strategies are given to students in teaching mathematics competencies, the development of students' critical thinking, collaboration, and selfregulation can be predicted to show good or high results.

\section{CONCLUSIONS}

Based on the aforementioned findings and analyses, the researcher concluded that the use of language and literacy strategies increased the level of competence of the respondents from the two class groups regardless of which section they belonged. This means that the more authentic literacy activities are given to students, the higher is their level of cognition and retention. Moreover, it can be generalized significantly that the relationship of the students' posttest scores and their basic need satisfaction scale results depends on the nature and type of assessments given to the students. It means that when process type of assessment increases, its relationship to the need for competence also increases. Furthermore, when the psychological needs of students are satisfied greatly, their level of academic performance also increases significantly. Therefore, it can predict a better performance in the posttest.

\section{REFERENCES}

1. Australian Curriculum. (2014). General capabilities and literacy. Retrieved from http://www.australiancurriculum.edu.au/generalcapabilities/literacy/introduction/introduction

2. Authentic Literacy Instruction. (n.d.). Creating authentic literacy activities $K-3$ (par. 2). Retrieved from http://cpls.educ.ubc.ca/content/pdfs/LiteracyInstruction.pdf

3. Barney et al. (2015). Quantitative descriptive-correlation research. eResearch Method, par. 3. Retrieved from http://www.erm.ecs.soton.ac.uk/authors/index.htm 
4. Barrot, J. (2014). A socio cognitive-transformative instructional materials design model for second language (L2) pedagogy in the Asia Pacific: development and validation. The Asia Pacific Education Researcher, 24, 283-297. doi:10.1007/s40299-014$0179-0$

5. Brown, J. (2004). Making the Most of Understanding by Design. Retrieved from http://www.ascd.org/publications/books/103110/chapters/Implementing-Understanding-by-Design@-A-Summary-of-LessonsLearned

6. de Leon, M. (2011, June 6). Philippine education ranked 'poor'. Philippine Daily Inquirer, par. 1.

7. Department of Education. (2013). Curriculum guide for grade four mathematics. Retrieved from http://www.deped.gov.ph/downloads/2012/01jan/MATHEMATICS-K-12-Curriculum-Guide.pdf

8. Duke, N., Purchell-Gates, V., Hall, L., \& Tower, C. (2015). Authentic literacy activities for developing comprehension and writing. Retrieved from http://www.academia.edu/165629/Authentic_literacy_activities_for_developing_comprehension_and_writing

9. Heidema, C. (2009, February). Reading and writing to learn in mathematics: strategies to improve problem solving. Adolescent Literacy in Perspective, pp. 2-9.

10. Heltemes, L. (2009). Social and Academic Advantages and Disadvantages of Within-class Heterogeneous and Homogeneous Ability Grouping. Mathematical and Computing Sciences Masters. Paper 93.

11. Hintz, A., \& Kazemi, E. (2014). Talking about math. Educational Leadership, 72(3), 37-40.

12. Kim, Y., \& Cho, Y. H. (2014). The second leap towards "World Class" education in Korea. The Asia Pacific Education Researcher, 24, 783-794. doi:10.1007/s40299-013-014403

13. Koh, E., Ponnusamy, L. D., Tan, L. S., Lee, S-S., \& Ramos, M. E. (2014). A Singapore case study of curriculum and innovation in the twenty-first century: demands, tensions, and deliberations. The Asia Pacific Education Researcher, 23, 851-860. doi:10.1007/s40299-014-0216-z

14. Lee, D. H. L., Hong, H., \& Niemi, H. (2014). A contextualized account of holistic education in Finland and Singapore: implications on Singapore educational context. The Asia Pacific Education Researcher, 23, 871-884. doi:10.1007/s40299014-0189-y

15. Leong, K. E. (2014). What are the important attributes of good mathematics teaching?. The Asia Pacific Education Researcher, 24, 211-223. doi:10.1007/s40299-014-0173-6

16. Liau, A., Kiat, J., \& Nie, Y. (2014). Investigating the pedagogical approaches related to changes in attitudes toward statistics in a quantitative methods course for psychology undergraduate students. The Asia Pacific Education Researcher, 24, 319-327. doi:10.1007/s40299-014-0182-5

17. Lin, T., Wang, L., Li, J., \& Chang, C. (2013). Pursuing quality education: the lessons from the education reform in Taiwan. The Asia Pacific Education Researcher, 23, 813-822. doi:10.1007/s40299-013-0135-4

18. Lunsford, A. A., \& Ruszkiewicz, J. J. (2009). Everything's an argument. New York: Bed fort St. Martin's.

19. Matheny, K. (2009, February). Addressing literacy in the science and mathematics classrooms. Adolescent Literacy in Perspective, pp. 17-20.

20. Meier, D. (2010). Are the national standards the right move? Educational Leadership, 67(7), p. 23.

21. Philips, V., \& Wong, C. (2010). Tying together the common core of standards, instruction, and assessments. Phi Delta 
Kappan, 91(5), pp. 37-42.

22. Rapatan, M. (2014, July). Designing, assessing and facilitating grade 10 learning units based on the $\mathrm{K}$ to 12 standards. In $R$. Ferrer (Chair), Trainers' training for grade 10standards. Training conducted by Private Education Assistance Committee Fund for Assistance to Private Education, Pampanga City.

23. Ryan, R., \& Deci, E. (2000). Self-determination theory and the facilitation of intrinsic motivation, social development, and well-being. American Psychologist, 55, 68-78. doi:10.1037//0003-066X.55.1.68

24. Schmoker, M. (2011). Making Math Meaningful. In E. Yermoli \& J. Houtz (Eds.), Focus: Elevating the Essentials to Radically Improve Student Learning (pp. 194-215). Alexandria, Virginia, USA: Association for Supervision and Curriculum Development.

25. So, K., \& Kang, J. (2014). Curriculum reform in Korea: issues and challenges for twenty-first century learning. The Asia pacific Education Researcher, 23, 795-803. doi:10.1007/s40299-013-0161-2

26. Statistical-correlation. (n.d.). In Explorable (2008-2015). Retrieved from https://explorable.com/

27. United Nations Educational, Scientific, and Cultural Organization. (2015). Literacy builds strong communities of learners (India). Retrieved from http://www.unesco.org/education/literacy/ 